\title{
Planting density and arrangement for the mechanized spraying of vertically staked tomatoes
}

\section{Anderson Fernando Wamser ${ }^{1}$; Janice Valmorbida ${ }^{1}$; Atsuo Suzuki'; Leandro Hahn ${ }^{1,2}$; Siegfried Mueller ${ }^{1}$; Walter F Becker' ${ }^{1}$; Anderson Luiz Feltrim ${ }^{1}$; Marcos M Ender ${ }^{2}$}

${ }^{1}$ Empresa de Pesquisa Agropecuária e Extensão Rural de Santa Catarina (Epagri), Caçador-SC, Brasil; afwamser@epagri.sc.gov.br; janicevalmorbida@epagri.sc.gov.br; atsuosuzuki17@gmail.com; simueller02@gmail.com; wbecker@epagri.sc.gov.br; andersonfeltrim@ epagri.sc.gov.br; ${ }^{2}$ Universidade Alto Vale do Rio do Peixe (Uniarp), Caçador-SC, Brasil; leandrohahn@epagri.sc.gov.br; marcos-ender@ hotmail

\begin{abstract}
We aimed to determine an adequate planting density and arrangement for the mechanized spraying of vertically staked tomatoes. Two experiments were carried out in the 2013/14 and 2014/15 harvests in the city of Calmon, state of Santa Catarina, Brazil, both in randomized block design. In 2013/14, treatments were arranged in a $4 \times 2$ factorial, corresponding to four planting densities $(10,753,12,903,16,129$ and 21,505 plants/ha) and two planting arrangements (single and double rows). In 2014/15, treatments were arranged in a $5 \times 2$ factorial, corresponding to five plant densities (the same planting densities of the previous harvest beyond 32,258 plants/ha) and the same planting arrangements. Total, marketable (considering extra AA and extra A fruits as marketable) and unmarketable yield, the average mass of marketable fruits and severity of leaf diseases were evaluated. Economic analysis was also performed. For tomatoes grown under mechanized spraying, double row plantings resulted in higher yield of marketable fruits and a higher percentage of top grade fruits compared to single row plantings. Maximum fruit yield was reached at approximately 34,000 plants/ ha, although maximum revenue was estimated for 23,000 plants/ha. Bacterial spot and Septoria leaf spot severity were higher in double rows than in single rows. Increases in planting density resulted also in increases in bacterial spot and early blight severity.
\end{abstract}

Keywords: Solanum lycopersicon, cropping system, mechanization, disease severity, economic analysis.

\begin{abstract}
RESUMO
Densidade e arranjo de plantas para pulverização mecanizada do tomateiro tutorado verticalmente

O objetivo do presente estudo foi determinar a melhor densidade e arranjo do tomateiro tutorado verticalmente para a pulverização mecanizada. Foram realizados dois experimentos nas safras 2013/14 e 2014/15 em Calmon-SC. Na safra 2013/14, o delineamento experimental foi em blocos ao acaso com arranjo fatorial $4 \times 2$, sendo combinados quatro densidades de plantas $(10.753,12.903,16.129$ e 21.505 plantas/ha) e dois arranjos de plantas tutoradas verticalmente (fila simples e fila dupla). Na safra 2014/15, o delineamento experimental foi em blocos ao acaso com arranjo fatorial $5 \times 2$, representado pela combinação de cinco densidades de plantas $(10.753,12.903,16.129$, 21.505 e 32.258 plantas/ha) e de dois arranjos de plantas tutoradas verticalmente (fila simples e fila dupla). Avaliou-se a produtividade total, comercial (extra AA e extra A) e descarte, a massa média de frutos comerciais (extra AA e extra A), a severidade de doenças foliares e procedeu-se a análise econômica dos tratamentos. $\mathrm{O}$ arranjo de plantas em fila dupla, para a pulverização mecanizada do tomateiro, proporcionou maior produtividade de frutos comerciais e com maior porcentagem de frutos de melhor classificação, em comparação ao arranjo de plantas em fila simples. A máxima produtividade de frutos foi obtida na densidade de aproximadamente 34.000 plantas/ha, embora a densidade em que se obtém o maior retorno econômico é estimada em 23.000 plantas/ha. As maiores severidades de mancha bacteriana e septoriose foram observadas no arranjo de plantas em fila dupla, em relação ao arranjo de plantas em fila simples. O aumento da densidade de plantas aumentou a severidade de mancha bacteriana e de pinta preta.
\end{abstract}

Palavras-chave: Solanum lycopersicon, sistema de cultivo, mecanização, severidade de doença, análise econômica.

Received on April 13, 2016; accepted on April 11, 2017

$\mathrm{T}_{\mathrm{r}}$ he city of Caçador and surrounding region (Lebon Régis, Rio das Antas, Macieira and Calmon) are the main tomato producer zone in the state of Santa Catarina and the second largest national table tomato producing area in summer (Carazzato et al., 2015). In harvest 2012/13, 1,122 ha were estimated to be used to grow tomatoes, with an average yield estimated at $79.6 \mathrm{t} / \mathrm{ha}$ (Anater, 2015). Sharecroppers and contracted employees are the predominant labor force in the region (Wamser et al., 2015) and labor represents approximately $30 \%$ of production costs (Deleo et al., 2015). Tomato demands intensive labor due to the several and repeated cultural practices required during the cycle as, for example, phytosanitary sprayings (Mueller et al., 2008). 
Sprays in Caçador region are numerous due to the high incidence of insect pests (Santos et al., 2008) and to the mild temperature and frequent rain observed between December and February, which favors the occurrence of the main tomato diseases (Becker, 2005). Sprays are predominantly manual, using stationary sprayers and spray rods, which constantly expose operators to drift, increasing intoxication risks (Santos, 2010). In addition, operator fatigue may reduce application efficiency along the work, which is also compromised by the shortage of qualified labor in the region (Wamser et al., 2015). Producers say high labor costs, risks of operator intoxication, deficiency in application and shortage of qualified labor justify the adoption of mechanized spraying systems in tomato. Systems in use consist of turbo atomizers coupled in the power take-off of narrow tractors, with an approximate width of $1.30 \mathrm{~m}$.

The use of mechanized sprayings affected crop management in tomatoes, especially in fields with vertical plant staking. Corridor spacing, between single rows, increased from 1.3-1.6 $\mathrm{m}$ (Mueller et al., 2008) to $2.0-2.2 \mathrm{~m}$ and arrangements in double vertical rows were adopted, using 0.8 to $1.0 \mathrm{~m}$ spacing within the double row. Double row plantings, for example in cross-over or inverted "V", can result in losing many advantages of vertical singlerow staking, among them spraying both sides of plants (Picanço et al., 1995). Spraying both sides increases plant phytosanitary coverage and the efficiency in controlling diseases and pest insects (Wamser et al., 2008; Becker et al. 2011). In addition, vertical plant staking in single rows increases the incidence of solar radiation and ventilation of plant canopies and, by reducing leaf wetness, reduces also disease severity (Santos et al., 1999).

Planting arrangements using single rows with reduced spacing between plants, keeping the same plant density currently used by producers in double rows, are alternatives to overcome problems inherent to double row plantings. It is also possible to broaden the spacing between plants in double rows, improving the efficiency of phytosanitary sprayings, with positive consequences on crop production. Any changes in the planting staking system have economic impacts and can increase or decrease production costs. This aspect should also be considered when choosing the best staking system for tomato.

The correct management of tomato fields for mechanized spraying needs studies, aiming to improve the control of diseases and insect pests and to allow also for high productivity, good fruit quality and economic return to producers. The objective of this work was to determine the best planting density and arrangement for mechanized spraying of vertically staked tomatoes.

\section{MATERIAL AND METHODS}

Two on-farm experiments were carried out during harvests 2013/14 and $2014 / 15$ in the city of Calmon, state of Santa Catarina, Brazil (26³7'43'S, $50^{\circ} 57^{\prime} 24^{\prime \prime} \mathrm{W}, 1,208 \mathrm{~m}$ altitude). The climate in the region is constant humid subtropical, with mild summers, Cfb type according to the Köppen classification. Soil at the experimental areas was classified as humic Cambisol (FAO, 1994) with the following attributes: $\mathrm{pH}($ water $)=6.1$ and $6.4, \mathrm{P}=19.8$ and $20.1 \mathrm{mg} / \mathrm{dm}^{3}, \mathrm{~K}=90$ and $246 \mathrm{mg} / \mathrm{dm}^{3}$, $\mathrm{OM}=38$ and $38 \mathrm{~g} / \mathrm{dm}^{3}, \mathrm{Al}=0.0$ and 0.0 $\mathrm{cmolc} / \mathrm{dm}^{3}, \mathrm{Ca}=8.8$ and $18.1 \mathrm{cmolc} /$ $\mathrm{dm}^{3}, \mathrm{Mg}=7$ and $4.8 \mathrm{cmolc} / \mathrm{dm}^{3}, \mathrm{~V} \%=79$ and 72 , in 2013/14 and 2014/15 seasons, respectively.

In 2013/14, treatments consisted of four planting densities $(10,753$, 12,903, 16,129 and 21,505 plants/ha) and two planting arrangements (single or double rows), with vertically staked plants, in a 4x2 factorial design. In 2014/15, treatments and plant staking were as in the previous harvest, but with one additional planting density (32,258 plants/ha), in a 5x2 factorial. In both years, experiments were set in randomized blocks, with four replications.

Experimental plots were $6.0 \mathrm{~m}$ long in all treatments. In double rows, internal spacing was $0.9 \mathrm{~m}$, with 2.1 $\mathrm{m}$ between double rows, while in-row spacings were $0.6,0.5,0.4,0.3$ and 0.2 $\mathrm{m}$, corresponding to $10,753,12,903$, 16,129, 21,505 and 32,258 plants/ha, respectively. In single rows, the spacing between rows was $2.1 \mathrm{~m}$ and, between plants, $0.42,0.35,0.28,0.21$ and 0.14 $\mathrm{m}$, corresponding to the same densities as in double rows. Sampling areas of experimental plots were 9.0 and $12.6 \mathrm{~m}^{2}$ for arrangements in double and single rows, respectively.

The indeterminate-growth tomato hybrid Paronset was used. Seedlings were produced in plastic trays, using a substrate of coconut-husk powder and vermiculite. Seedlings were transplanted to the field on November 22, 2013, and November 26, 2014. Furrow planting fertilization consisted of $50 \mathrm{~kg} / \mathrm{ha} \mathrm{N}$ as ammonium nitrate, $20 \mathrm{~kg} / \mathrm{ha}$ of $\mathrm{K}_{2} \mathrm{O}$ as potassium chloride, $300 \mathrm{~kg} / \mathrm{ha}$ of $\mathrm{P}_{2} \mathrm{O}_{5}$ as triple superphosphate, $7 \mathrm{t} /$ ha of poultry litter and $5 \mathrm{~kg} / \mathrm{ha}$ of B as borax, in both years. Split fertilization was carried out weekly, starting 21 days after planting (DAP) and summing up $450 \mathrm{~kg} / \mathrm{ha}$ of $\mathrm{N}$ and $475 \mathrm{~kg} / \mathrm{ha}$ of $\mathrm{K}_{2} \mathrm{O}$ using the same sources as for furrow fertilization, also in both seasons.

Plastic ribbons were used to vertically stake plants, which were conducted with two stems and periodic sprout pruning. Sprayings were carried out using a turbo atomizer model ARBO 480 (Montana, São José dos Pinhais, Brazil), coupled to the power take-off of a tractor model Montana 40 (Landini, Fabbrico, Italy), using volumes from $200 \mathrm{~L} /$ ha (from the beginning of the cycle to the beginning of harvest) to $550 \mathrm{~L} /$ ha (from the beginning to the end of harvest). Products used are registered to tomatoes and target pests and withholding periods were observed (Ministério da Agricultura, Pecuária e Abastecimento, 2016). Other cropping practices were carried out according to technical indications for staked tomatoes in the region of the Alto Vale do Rio do Peixe (Mueller et al., 2008).

Tomatoes were harvested weekly as fruits reach the harvest point that is when apical ends turned reddish. Total, marketable (fruits extra AA, larger than 
$150 \mathrm{~g}$; and extra A, between 100 and $150 \mathrm{~g})$ and unmarketable yield were assessed, as well as average mass of marketable fruits (extra AA and extra A). Unmarketable yield corresponded to both small (less than $100 \mathrm{~g}$ ) and damaged fruits, either physiological damages or injuries caused by diseases or insect pests. Disease severity, as function of the natural occurrence of late (Phytophthora infestans) and early (Alternaria solani) blight, bacterial spot (Xanthomonas campestris pv. vesicatoria) and Septoria leaf spot (Septoria lycopersici), was also assessed, 131 and 105 days after planting (DAP) in 2013/14 and 2014/15, respectively. Symptom severity was measured using diagrammatic scales for late (James, 1971) and early (Boff et al., 1991) blights and bacterial spot (Mello et al., 1997). For the Septoria leaf spot, the percentage of infected leaf area was evaluated by means of a diagrammatic scale previously developed (Walter Ferreira Becker, unpublished data).

For economic analysis, average prices for $23 \mathrm{~kg}$-box of extra AA tomatoes paid to producers at Caçador from February to April in 2014 and in 2015 (Sabio et al., 2014, 2015), corresponding to US\$ 14.4 and US\$ 11.6, respectively, were considered. Prices paid to extra A fruits were assumed as $65 \%$ of prices paid to extra AA fruits. Production costs in 2013/14 and 2014/15 were taken as described by Deleo et al. (2015), adjusting costs of seeds, nursery, seedling replanting and stakes (plastics or bamboo) according to planting densities and the need for temporary labor. Cost analysis considered an employee for each 5,500 plants, receiving the current minimum wage and a commission of US\$ 0.56 and US\$ 0.47 per harvested box in 2013/14 and 2014/15, respectively (Deleo et al., 2015). Other production costs, such as inputs (fertilizers, lime, pesticides and adjuvants), infrastructure (maintenance and replacement), mechanical operations, irrigation, fixed labor, expenses with implements, general expenses, land leasing, working capital financing and the annual cost for asset renewal (ACAR) were assumed to be fixed in all treatments.

Data were submitted to analysis of variance ( $F$ test). Once significant differences were detected $(\mathrm{p} \leq 0.05)$, polynomial adjustments for plant density were applied. Statistical analysis was performed using the package ExpDes (v.1.1.2) of the software R (v.3.1.2).

\section{RESULTS AND DISCUSSION}

There was no significant interaction ( $p>0.05$ ) between planting arrangement and density for none of the evaluated characteristics. Therefore, only simple effects of each factor were studied.

Planting arrangement in double rows resulted in higher total and marketable yield in both harvests, as well as in higher yield of extra AA fruits in 2013/14 and higher yield of extra A fruits in 2014/15, compared to single rows (Figures 1 and 2). In 2013/14, marketable and extra AA fruits produced in double rows had higher average mass and therefore extra AA fruits had a significantly higher contribution to total marketable yield than when plants were arranged in single rows (Table 1). On the other hand, in 2014/15, the average mass of extra A fruits was higher in plants in single than in double rows (Table 1).

These results indicate that, for

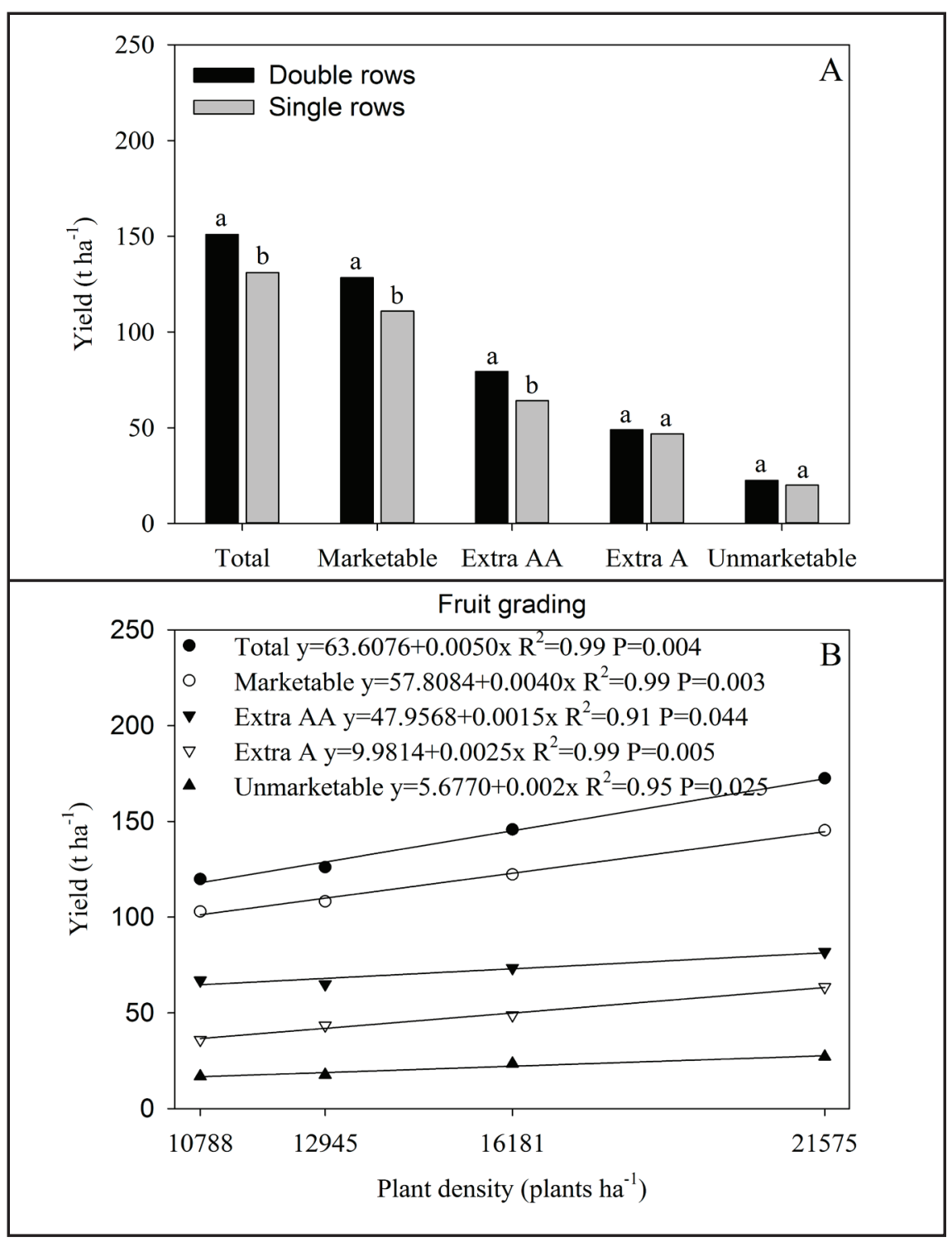

Figure 1. Total, marketable, extra AA, extra A, and unmarketable fruit yield of tomatoes grown under mechanized spraying as function of planting arrangement (A) and density (B), 2013/14 harvest. Means followed by the same letter in each fruit class do not differ from each other, F test, $\mathrm{p}>0.05$. Caçador, Epagri, 2015. 
tomato mechanized spraying, planting arrangements in double rows significantly increase yield and fruit quality in relation to plantings in single rows, which is likely to be due to the larger in-row spacing in double rows in relation to single rows. Broadening inrow spacing increases fruit production per plant up to a threshold (Azevedo et al., 2010). Thus, for a given plant density, arrangements with larger spacing between plants result in higher yields, as we observed.

The severity of both bacterial spot, in 2013/14, and Septoria leaf spot, in $2014 / 15$, were higher in double row than in single row plantings (Table 2), strengthening the hypothesis that, for plant vertical staking, double row planting favors disease occurrence when compared to single row. Possibly, sprayings on only the plant side facing the row reduce fungicide coverage and, thus, fungicide efficiency. It is also possible that the internal row in the double row is less ventilated and consequently more humid, enhancing the pro-disease microenvironment. Wamser et al. (2008) and Becker et al. (2011) observed similar results when comparing vertical and cross staking systems, in which plants are also sprayed only on the side facing the row.

The highest productivity in double rows resulted in higher net revenue in double rows than in single rows in both years (Table 3 ). In 2013/14, net revenue from double row plantings was US\$ 9,866.10 higher than those obtained in single rows. In 2014/15, the increase in net revenue in double rows was US\$ $2,403.74$ in relation to single rows. These increases represented gains of 35.7 and $9.7 \%$, respectively, in double row plantings in relation to single row arrangements. The highest increase in 2013/14 was mainly due to the higher yield of extra AA fruits observed in this harvest in double rows when compared to single rows (Figure 1). In 2014/15, there were no significant differences between planting arrangements for yield of extra AA fruits. In addition, yield of extra A fruit was significantly higher in single rows than in double rows in this harvest (Figure 2). Emphasis must be given to the great impact extra AA fruits have in revenues, since extra AA fruits have higher commercial value than extra A fruits (CEAGESP, 2016).

Increases in planting density raised the productivity for all fruit classes in 2013/14 (Figure 1). Data adjustments resulted in linear models and, therefore, no maximum technical efficiency was reached within the planting density range studied. Effects of planting density on increasing tomato yield are well described in literature (Azevedo et al., 2010; Wamser et al., 2009, 2012). Nevertheless, determination of the optimum density, in which maximum marketable fruit yield would be reached, has been receiving little attention.

In 2014/15, increases in planting density also increased productivity in all fruit classes, except for extra AA fruits (Figure 2). As one more level in the planting density factor was included in this harvest $(32,258$ plants/ ha), quadratic adjustments for total and marketable fruit yield, as well as for yield of extra A fruits, were obtained. Yet, models indicate maximum technical efficiencies to be reached above the maximum plant densities evaluated, that is, $38,189,33,892$ and 34,465 plants/ha,

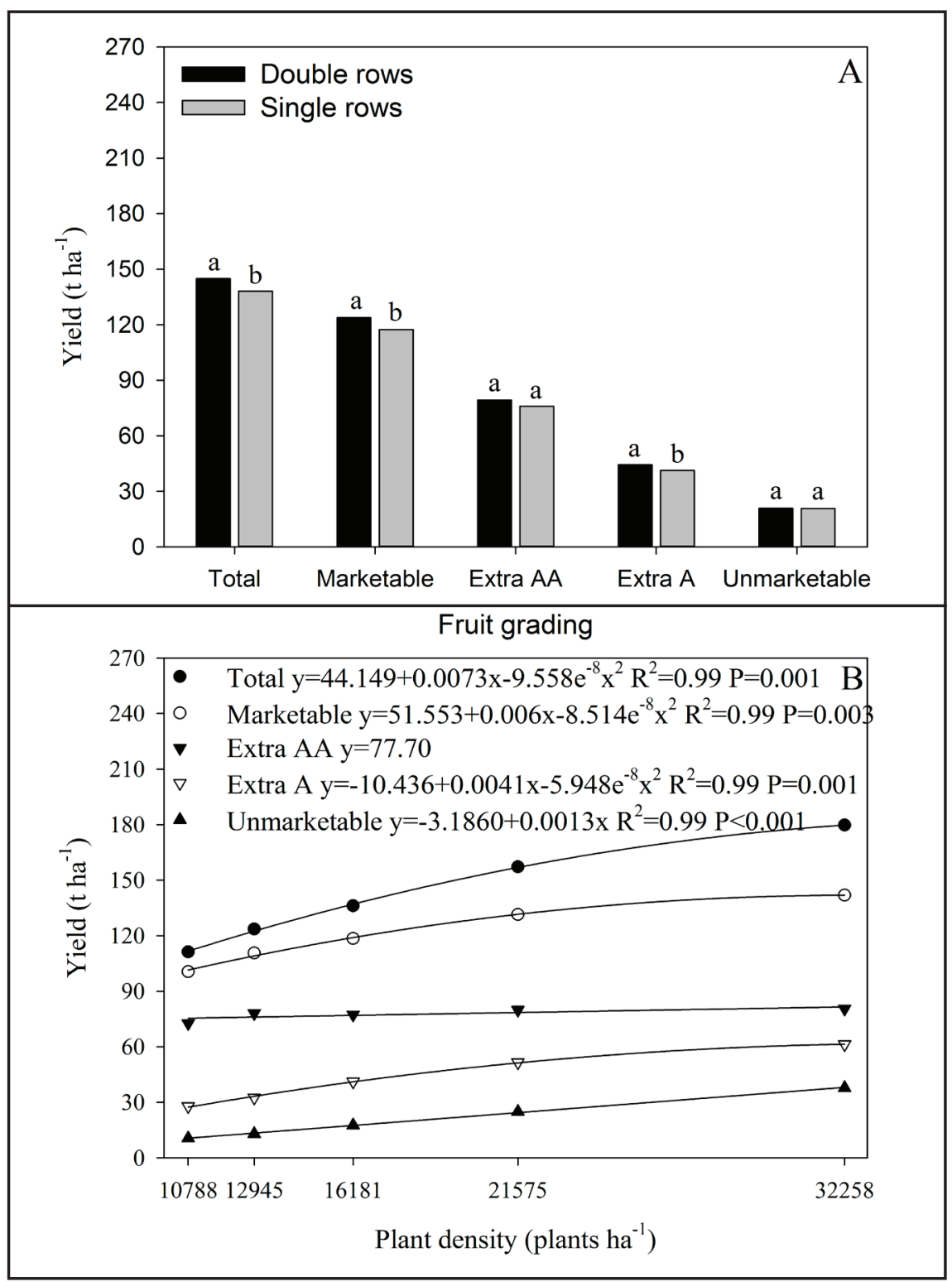

Figure 2. Total, marketable, extra AA, extra A, and unmarketable fruit yield of tomatoes grown under mechanized spraying as function of planting arrangement (A) and density (B), 2014/15 harvest. Means followed by the same letter in each fruit class do not differ from each other, F test, p>p0.05. Caçador, Epagri, 2015. 
Table 1. Mass of marketable, extra AA and extra A tomatoes, percentage of marketable fruits in total production and percentage of extra AA fruits in marketable production, for plants grown under mechanized spraying as function of planting arrangement and density, 2013/14 and 2014/15 harvests. Caçador, Epagri, 2015.

\begin{tabular}{|c|c|c|c|c|c|c|}
\hline \multirow{2}{*}{$\begin{array}{l}\text { Factor } \\
\text { levels }\end{array}$} & \multicolumn{3}{|c|}{ Harvest 2013/14, fruit average mass (g) } & \multicolumn{3}{|c|}{ Harvest $2014 / 15$, fruit average mass $(\mathrm{g})$} \\
\hline & Marketable & Extra AA & Extra A & Marketable & Extra AA & Extra A \\
\hline \multicolumn{7}{|c|}{ Planting arrangement } \\
\hline Double-rows & $156.4^{* *}$ & $184.1^{* *}$ & $120.9^{\mathrm{ns}}$ & $152.9^{\mathrm{ns}}$ & $174.8^{\mathrm{ns}}$ & $123.7^{* *}$ \\
\hline Single-rows & 152.1 & 175.6 & 122.4 & 154.0 & 174.9 & 125.3 \\
\hline \multicolumn{7}{|c|}{ Planting density (plants/ha) } \\
\hline 10,788 & $156.4^{* *}$ & $183.3^{* *}$ & $123.0^{\mathrm{ns}}$ & $161.5^{* *}$ & $180.6^{* *}$ & $126.6^{* *}$ \\
\hline 12,945 & 152.1 & 181.8 & 122.2 & 159.5 & 178.6 & 126.8 \\
\hline 16,181 & 149.3 & 177.0 & 121.0 & 153.0 & 173.6 & 125.0 \\
\hline 21,575 & 147.2 & 177.2 & 120.6 & 149.0 & 172.9 & 122.7 \\
\hline 32,258 & - & - & - & 144.3 & 168.6 & 121.3 \\
\hline Regression & $y=163.4777-0.0008 x$ & $\mathrm{y}=188.9187-0.0006 \mathrm{x}$ & $\mathrm{y}=121.7$ & $\mathrm{y}=184.1871-0.0025 \mathrm{x}+3.895 \mathrm{e}^{-8} \mathrm{x}^{2}$ & $=184.6939-0.000$ & $29.5582-0.0003 x$ \\
\hline $\mathbf{R}^{2}$ & 0.88 & 0.75 & - & 0.99 & 0.88 & 0.92 \\
\hline $\begin{array}{l}\text { Factor } \\
\text { levels }\end{array}$ & $\begin{array}{c}\text { Marketable/ } \\
\text { total fruit } \\
\text { production (\%) }\end{array}$ & $\begin{array}{l}\text { Extra AA/mar } \\
\text { fruit producti }\end{array}$ & $\begin{array}{l}\text { ketable } \\
\text { ion }(\%)\end{array}$ & $\begin{array}{l}\text { Marketable/total fruit } \\
\text { production (\%) }\end{array}$ & $\begin{array}{r}\text { Extra AA } \\
\text { proc }\end{array}$ & $\begin{array}{l}\text { etable fruit } \\
n(\%)\end{array}$ \\
\hline \multicolumn{7}{|c|}{ Planting arrangement } \\
\hline Double-rows & $85.2^{\mathrm{ns}}$ & $62.2^{* *}$ & & $86.1^{\mathrm{ns}}$ & & \\
\hline Single-rows & 84.7 & 57.9 & & 85.7 & & \\
\hline \multicolumn{7}{|c|}{ Planting density (plants/ha) } \\
\hline 10,788 & $85.8^{\mathrm{ns}}$ & $64.4^{* *}$ & & $90.4^{* *}$ & & \\
\hline 12,945 & 85.8 & 59.8 & & 89.5 & & \\
\hline 16,181 & 83.8 & 59.9 & & 87.0 & & \\
\hline 21,575 & 84.5 & 56.3 & & 83.6 & & \\
\hline 32,258 & - & - & & 78.9 & & \\
\hline Regression & $\mathrm{y}=85.0$ & $\mathrm{y}=70.0439-0$. & $.0006 x$ & $y=96.1176-0.0005 x$ & $y=92.7444-$ & $\mathrm{x}+3.425 \mathrm{e}^{-8} \mathrm{x}^{2}$ \\
\hline $\mathbf{R}^{2}$ & - & 0.84 & & 0.99 & & \\
\hline
\end{tabular}

** = significant, $\mathrm{F}$ test, $\mathrm{p}>0.01 ;{ }^{\mathrm{ns}}=$ non-significant.

respectively for total, marketable and extra A fruit yield. Streck et al. (1998) observed maximum yield of marketable tomatoes with 43,862 plants/ha, in protected cultivation.

In $2013 / 14$, there were increases of $43.9,41.2,22.2,76.6$ and $60.7 \%$ in total, marketable, extra AA, extra A and unmarketable fruit yield, respectively, from the lowest to the highest planting density. The increase in productivity of extra A fruit, whose commercial value is lower than extra AA fruits, had stronger influence on the increase in marketable yield as function of the rising planting densities than the increase of extra AA fruits, whose commercial value is higher than that of extra A fruits. Participation of extra AA fruits in marketable production fell (Table 1), although not enough to have significantly reduced the marketable yield contribution to total yield (Table 1).

In $2014 / 15$, increases in total, marketable, extra A and unmarketable fruit yield were 61.6, 41.1, 119.9 and $256.2 \%$, respectively, from the lowest to the highest density. The increase in productivity of extra A fruits, with lower commercial value than extra AA fruits, was the only factor increasing marketable productivity as function of the mounting plant densities. As consequence, the proportion of extra AA fruits in marketable production declined (Table 1). In this harvest, as there was no increase in yield of extra AA fruits as function of increases in density, marketable fruit participation in total yield fell (Table 1).

Marketable, extra AA and extra A fruit mass decreased with the increase in planting density in both years, except for extra A fruit mass in 2013/14, when there were no significant differences in extra A fruit mass as function of variation in planting density (Table 1). Decreases in fruit quality (fruit grading and mass) related to increases in planting density are well described in literature for tomatoes (Azevedo et al., 2010; Wamser et al., 2009, 2012) and are due to competition between plants (Papadopoulos \& Pararajasingham, 
Table 2. Leaf disease severity in tomato grown under mechanized spraying as function of planting arrangement and density, 2013/14 and 2014/15 harvests. Caçador, Epagri, 2015.

\begin{tabular}{|c|c|c|c|c|}
\hline \multirow{2}{*}{ Factor level } & Bacterial spot & Early blight $^{1}$ & Late blight $^{1}$ & Septoria leaf spot ${ }^{1}$ \\
\hline & \multicolumn{4}{|c|}{ Harvest 2013/14 } \\
\hline \multicolumn{5}{|c|}{ Planting arrangement } \\
\hline Double-rows & $37.44^{*}$ & - & - & - \\
\hline Single-rows & 28.81 & - & - & - \\
\hline \multicolumn{5}{|c|}{ Planting density (plants/ha) } \\
\hline 10,788 & $27.75^{\mathrm{ns}}$ & - & - & - \\
\hline 12,945 & 35.13 & - & - & - \\
\hline 16,181 & 32.88 & - & - & - \\
\hline 21,575 & 36.75 & - & - & - \\
\hline
\end{tabular}

\begin{tabular}{|c|c|c|c|c|}
\hline & \multicolumn{4}{|c|}{ Harvest 2014/15 } \\
\hline \multicolumn{5}{|c|}{ Planting arrangement } \\
\hline Double-rows & $35.23^{\mathrm{ns}}$ & $0.44^{\mathrm{ns}}$ & $0.01^{\mathrm{ns}}$ & $2.07^{* *}$ \\
\hline Single-rows & 33.50 & 0.49 & 0.01 & 0.74 \\
\hline \multicolumn{5}{|c|}{ Planting density (plants/ha) } \\
\hline 10,788 & $29.13^{*}$ & $0.28^{*}$ & $0.01^{\text {ns }}$ & $1.46^{\mathrm{ns}}$ \\
\hline 12,945 & 30.00 & 0.31 & 0.00 & 0.74 \\
\hline 16,181 & 35.31 & 0.31 & 0.01 & 0.92 \\
\hline 21,575 & 35.00 & 0.66 & 0.03 & 1.79 \\
\hline 32,258 & 42.38 & 0.75 & 0.01 & 2.09 \\
\hline Regression & $\mathrm{y}=23.2310+0.0006 \mathrm{x}$ & $\mathrm{y}=0.0049+2.4382 \mathrm{e}^{-5} \mathrm{x}$ & - & - \\
\hline $\mathbf{R}^{2}$ & 0.93 & 0.87 & - & - \\
\hline
\end{tabular}

1/ Early and late blight and Septoria leaf spot did not occurr in 2013/14. ${ }^{*}$ Factor levels differed significantly from each other, F test, P $>$ $0.05 ;{ }^{* *}$ Factor levels differed significantly from each other, F test, $\mathrm{P}>0.01$. ${ }^{\text {ns }} /$ There were no significant differences between factor levels, $\mathrm{F}$ test, $\mathrm{P}>0,05$.

1997).

Increases in planting density resulted in higher severity of bacterial spot and early blight (Table 2). Wamser et al. (2012) observed related results for early blight and emphasize increments on plant density favor disease occurrence in tomatoes.

Net revenue increased with planting densities in both harvests (Table 3 ). In $2013 / 14$, increases in net revenue followed a linear adjustment [net revenue (NR), in US\$/ha, NR=13,906.9846 $+1.1966 \mathrm{x}$ density], resulting in US\$ $12,234.98$ or $43.5 \%$ increase in net revenue in the highest density in relation to the lowest. In 2014/15, increases in net revenue followed a quadratic adjustment [Net revenue (NR), in $\mathrm{US} \$ /$ ha, $\mathrm{NR}=11,742.1358+1.4105$ $\mathrm{x}$ density $-3.0631 \mathrm{e}^{-5} \mathrm{x}$ density $\left.{ }^{2}\right]$. In 2014/15, maximum economic efficiency was estimated with 23,033 plants/ha, a density 2.1 times greater than what is commonly used by producers of Caçador region, in general, 11,000 plants/ha (Deleo et al., 2015). Net revenue increase observed in the highest in relation to the lowest planting densities evaluated was US\$ 5,111.60 or $22.4 \%$.

Increases in planting density lead to increases also in labor cost. Nevertheless, labor cost can be compensated for by increasing efficiency, namely the number of plants each worker handles. According to Oliveira (2006), in highdensity tomato fields, the number of plants managed per unit of labor is larger than in fields with lower planting densities. For example, in production systems with 44,000 stems per hectare, it is possible for each worker to handle about 13,000 stems per cycle (Oliveira, 2006), while in the traditional systems, with 22,000 stems per hectare, each worker handles not more than 11,000 stems per cycle (Deleo et al., 2015). Thus, the high number of plants managed by each worker may, in fact, contribute to improving revenues at higher planting densities.

In crops with mechanized spraying, planting arrangements in double rows resulted in higher marketable fruit yield and higher percentage of fruits with good grading than arrangements in single rows, in the studied region. The highest yield was estimated with approximately 34,000 plants per hectare. Nevertheless, the highest economic return (net revenue) was estimated to take place with 23,000 plants per hectare. Bacterial spot and Septoria leaf spot severity were higher in double row than in single rows plantings. Increases in plant density led to increases in both 
Table 3. Net revenue of tomatoes grown under mechanized spraying as function of planting arrangement and density, harvests $2013 / 14$ and 2014/15. Caçador, Epagri, 2015.

\begin{tabular}{|c|c|c|c|c|c|c|}
\hline \multirow[b]{2}{*}{ Factor level } & \multirow[b]{2}{*}{ Gross revenue } & \multicolumn{4}{|c|}{ Cost (US\$/ha) } & \multirow[b]{2}{*}{ Net revenue } \\
\hline & & $\begin{array}{l}\text { Seeds and } \\
\text { seedlings }\end{array}$ & $\begin{array}{c}\text { Staking } \\
\text { material }^{1}\end{array}$ & Labor $^{2}$ & Total $^{3}$ & \\
\hline & \multicolumn{6}{|c|}{ Harvest 2013/14 } \\
\hline \multicolumn{7}{|c|}{ Planting arrangement } \\
\hline Double-rows & $69,677.33$ & $2,211.09$ & $1,183.97$ & $10,726.27$ & $32,207.12$ & $37,470.21$ \\
\hline Single-rows & $59,219.40$ & $2,211.09$ & $1,010.12$ & $10,308.30$ & $31,615.29$ & $27,604.11$ \\
\hline \multicolumn{7}{|c|}{ Planting density (plants/ha) } \\
\hline 10,788 & $56,559.06$ & $1,551.70$ & 951.59 & $7,833.01$ & $28,422.10$ & $28,136.96$ \\
\hline 12,945 & $58,338.47$ & $1,861.96$ & $1,020.03$ & $9,037.68$ & $30,005.46$ & $28,333.00$ \\
\hline 16,181 & $65,818.61$ & $2,327.41$ & $1,122.70$ & $10,979.79$ & $32,515.70$ & $33,302.91$ \\
\hline 21,575 & $77,073.26$ & $3,103.27$ & $1,293.84$ & $14,218.41$ & $36,701.32$ & $40,371.94$ \\
\hline \multicolumn{7}{|c|}{ Harvest 2014/15 } \\
\hline \multicolumn{7}{|c|}{ Planting arrangement } \\
\hline Double-rows & $54,407.74$ & $1,762.87$ & 915.07 & $8,819.88$ & $26,662.37$ & $27,745.38$ \\
\hline Single-rows & $51,748.28$ & $1,762.87$ & 787.70 & $8,691.52$ & $26,406.64$ & $25,341.64$ \\
\hline \multicolumn{7}{|c|}{ Planting density (plants/ha) } \\
\hline 10,788 & $45,651.80$ & $1,237.16$ & 730.61 & $5,668.18$ & $22,800.49$ & $22,851.31$ \\
\hline 12,945 & $49,883.71$ & $1,484.52$ & 787.44 & $6,597.62$ & $24,034.12$ & $25,849.59$ \\
\hline 16,181 & $52,314.66$ & $1,855.62$ & 872.69 & $7,847.41$ & $25,740.27$ & $26,574.39$ \\
\hline 21,575 & $56,999.33$ & $2,474.20$ & $1,014.80$ & $9,926.72$ & $28,580.26$ & $28,419.06$ \\
\hline 32,258 & $60,545.44$ & $3,699.31$ & $1,296.24$ & $13,738.87$ & $33,898.97$ & $26,646.47$ \\
\hline
\end{tabular}

1/ Wires and anchor and regular stakes - polythene strips and bamboo; $2 /$ Monthly wages, labor charges and commission per harvested box;

3/ Refer to variable costs, dependent of evaluated factors - seeds and seedlings, material for staking and labor - and fixed costs, independent of evaluated factors, namely US\$ 18,085.80 and US\$ 14,426.22 per hectare in 2013/14 and 2014/15 harvests, respectively (Deleo et al., 2015). Reference exchange rates: R\$ $1,00=\mathrm{US} \$ 0,42$, in March 15, 2014; R\$ 1,00 = US\$ 0,31, in March 15, 2015.

bacterial spot and early blight severity.

\section{ACKNOWLEDGMENTS}

Authors would like to thank the National Council for Scientific and Technological Development (CNPq) and the Foundation for Research and Innovation Support of the state of Santa Catarina (FAPESC), for financial support. Authors would like to thank also the farmers Fábio and James Brusco, for making available the areas where experiments were carried out and for supporting experiment implementation.

\section{REFERENCES}

ANATER, EU. 2015. Tomate. In: EPAGRI-
CEPA. Sintese anual da agricultura de Santa Catarina: 2014-2105. Florianópolis: EpagriCepa. p.63-65.

AZEVEDO, VF; ABBOUD, ACS; CARMO, MGF. 2010. Row spacing and pruning regimes on organically grown cherry tomato. Horticultura Brasileira 28: 389-394.

BECKER, WF. 2005. Validação de dois sistemas de previsão para o controle da requeima do tomateiro na região de Caçador, SC. Agropecuária Catarinense 18: 63-68.

BECKER, WF; MUELLER, S; SANTOS, JP; WAMSER, AF; SUZUKI, A; MARCUZZO, LL. 2011. Viability of a prediction system for tomato late blight in the integrated production of tomato in Caçador, Brazil. Horticultura Brasileira 29: 520-525.

BOFF, P; ZAMBOLIM, L; VALE, FXR. 1991. Escalas para avaliação de severidade da mancha-de-estenfílio (Stemphylium solani) e da pinta-preta (Alternaria solani) em tomateiro. Fitopatologia Brasileira 16: 280-283.

CARAZZATO, CA; CASALE, DE; BRITO JUNIOR, JS; TANUS, TCT. 2015. Tomate: clima instável e custo em alta devem limitar investimentos para 2016. Hortifruti Brasil
14: $18-21$.

CEAGESP. 2016. Cotações - Preços no Atacado. Available in: http://www.ceagesp.gov.br/ entrepostos/servicos/cotacoes/. Accessed in: February 05, 2016.

DELEO, JPB; TANUS, TCT; BOTEON, M. 2015. Gestão sustentável: tomate. Hortifruti Brasil 14: 10-26.

FAO. 1994. World reference base for soil resources: draft. Paris: Unesco. 161p.

JAMES, WC. 1971. An illustrated series of assessment keys for plant diseases. Their preparations and usages. Canadian Plant Disease Survey 51: 39-65.

MELLO, SC; TAKATSU, A; LOPES, CA. 1997. Escala diagramática para avaliação da mancha bacteriana do tomateiro. Fitopatologia Brasileira 22: 447-448.

MAPA. 2016. Agrofit. Available in: http://agrofit. agricultura.gov.br/agrofit_cons/principal agrofit_cons. Accessed in: September 13, 2016.

MUELLER, S; WAMSER, AF; BECKER, WF; SANTOS, JP. 2008. Indicações técnicas para o tomateiro tutorado na região do Alto Vale do Rio do Peixe. Florianópolis: Epagri. 78p. (Sistemas de Produção, 45). 
OLIVEIRA, MLC. 2006. Produção de tomate superadensado. Revista Campo \& Negócios HF, dez. 2006. Available in: http://www.revistacampoenegocios.com.br/ anteriores/12-06/index.php.

PAPADOPOULOS, AP; PARARAJASINGHAM, S. 1997. The influence of plant spacing on light interception and use in greenhouse tomato (Lycopersicon esculentum Mill.): a review. Scientia Horticulturae 69: 1-29.

PICANÇO, M; GUEDES, RNC; LEITE, GLD; FONTES, PCR; SILVA, EA. 1995. Incidência de Scrobipalpuloides absoluta em tomateiro sob diferentes sistemas de tutoramento e de controle químico. Horticultura brasileira 13: $180-183$.

SABIO, RP; PAGLIUCA, LG; JULIÃO, L; DELEO, JPB; BOTEON, M. 2014. Anuário 2014/15. Hortifruti Brasil 13. (Caderno de estatísticas).

SABIO, RP; PAGLIUCA, LG; JULIÃO, L; DELEO, JPB; BOTEON, M. 2015. Anuário 2015/16. Hortifruti Brasil 14. (Caderno de estatísticas).
SANTOS, HNG. 2010. Avaliação qualitativa da exposição dos aplicadores aos pesticidas em diversas culturas e equipamentos. In: REUNIÃO ANUAL DA SBPC, 62. Resumos... Natal: SBPC. Available in: http://www.sbpcnet. org.br/livro/62ra/resumos/resumos/1046.htm. Accessed in March 10, 2016.

SANTOS, HS; PERIN, WH; TITATO, LG; VIDA, JB; CALLEGARI, O. 1999. Avaliação de sistemas de condução em relação à severidade de doenças e à produção do tomateiro. Acta Scientiarum 21: 453-457.

SANTOS, JP; BECKER, WF; WAMSER, AF; MUELLER, S; ROMANO, F. 2008. Incidência de machos adultos de traça-do-tomateiro nos sistemas de produção convencional e integrada de tomates em Caçador, SC. Agropecuária Catarinense 21: 66-73.

STRECK, NA; BURIOL, GA; ANDRIOLO, JL; SANDRI, MA. 1998. Influência da densidade de plantas e poda apical drástica na produtividade do tomateiro em estufa de plástico. Pesquisa Agropecuária Brasileira 33: 1105-1112.
WAMSER, AF; BECKER, WF; MUELLER, S; SANTOS, JP. 2008. Influência do sistema de condução do tomateiro sobre a incidência de doenças e insetos-praga. Horticultura Brasileira 26: 180-185.

WAMSER, AF; BECKER, WF; MUELLER, S; SUZUKI, A; VALMORBIDA, J; FELTRIM, AL; SANTOS, JP; ROSSET, V; TOMAZELLI, A. 2015. Análise de correspondência múltipla para caracterização de produtores rurais por práticas agrícolas: tomaticultura em Caçador, Brasil. Revista de Ciências Agroveterinárias 14: 75-83.

WAMSER, AF; MUELLER, S; BECKER, WF; SANTOS, JP; SUZUKI, A. 2009. Espaçamento entre plantas e cachos por haste no tutoramento vertical do tomateiro. Horticultura Brasileira 27: 565-570.

WAMSER, AF; MUELLER, S; SUZUKI, A; BECKER, WF; SANTOS, JP. 2012. Produtividade de híbridos de tomate submetidos ao cultivo superadensado. Horticultura Brasileira 30: 168-174. 